\title{
Field comparison of drip and hose reel irrigation performance: results of a three year research project in Italy
}

\author{
G. Ghinassi \\ University of Florence, Italy
}

\begin{abstract}
Drip irrigation is considered the distribution technique most suited to combine water saving and good yield, due to intrinsic potential and advanced technology. With respect to other systems, correct use of drip technology requires that particular attention is paid to each component of the irrigation context, such as soil, crop and climate, in addition to design and maintenance. Recent research projects carried out at farm and field level in homogeneous areas, showed that drip performance is frequently lower than expected with regard to yield and water supplied on seasonal basis, and that similar or better responses are given by sprinkler systems operating in the same area during the same season. This paper illustrates results of a triennial research project, carried out from 2009 to 2011 in North Italy, to compare drip and hose reel sprinkler irrigation of annual crops under the same agronomical and climatic conditions. Analysis of 22 case studies (11 comparisons) shows similar crop yield response under drip and hose reel irrigation, while irrigation efficiency of drip is lower than sprinkler in most cases. According to project outcomes, selection and management of irrigation system is of paramount importance for sustainable irrigation.

Keywords: irrigation efficiency, drip irrigation, hose reel machines, sprinkler irrigation, irrigation management.
\end{abstract}

\section{Introduction}

From 2005 to 2007, a research project on irrigation water use was carried out in Tuscany, Central Italy, under the scientific and technical supervision of the University of Florence. In the framework of the project activity, micro-irrigation of annual crops was assessed on seasonal basis in 11 fields (cropping units), 
according to a comprehensive approach including crop evapotranspiration (ETc), net irrigation requirement (NIR), and seasonal (e.g., gross) irrigation supply (SIS). Such evaluation was made in order to understand how efficient micro irrigation was when carried out under actual farming conditions. Each unit was analyzed according to measured Low Quarter Distribution Uniformity (DUlq) and irrigation efficiency (IE) defined as the ratio NIR/SIS. Since cultivation of annual crops in the investigated farms aimed to yield maximization, SIS was assumed to be the amount of water supplied to avoid any water deficit during the season. According to processed data, average DUlq and IE were 0.76 and $63.2 \%$ respectively [1]. Crops cultivated in different farms of the same area gave similar response in terms of yield and supplied water during the same season [2], regardless of the irrigation type and despite lower DUlq of sprinkler systems. Notwithstanding system comparison was not allowed, such responses represented a challenge to understand how micro and sprinkler systems perform under the same agronomic conditions and management capacity.

In 2009, Department of Agricultural, Economics, Engineering, Sciences and Technologies (DEISTAF, University of Florence) was requested to compare performance of drip and hose reel sprinkler irrigation when working under the same conditions (e.g., farm, season, crop, climate, farmer's skills). The research was arranged in a case study assessing agronomical, economical and irrigation performance. Each case study refers to a specific crop irrigated during an individual irrigation season and cultivated in a field representative of the farm characteristics (e.g., soil type).

This paper reports the outcomes on irrigation performance as resulted from 22 case studies (11 comparisons).

\section{Methods and materials}

\subsection{Farms characteristics}

Field activity was carried out from 2009 to 2011 in medium sized farms, from 50 to 170 ha, representative in regard to cultivated crops and business type. Farms were selected on condition that farmers have good experience and skills of irrigation practice under both drip and hose reel machines, without any preference towards one system or the other, and that irrigation was practiced to yield maximization (e.g., full replacement of evapotranspiration losses). No other beneficial use was assigned to irrigation water in the project farms. Both irrigation systems were arranged and managed in fields similar in size, according to the normal procedure practised in each farm. Project farms were located in the Po valley, the most extended Italian lowland, and ground slope of all fields was minimal.

\subsection{Irrigation systems}

Low quarter distribution uniformity (DUlq) of drip systems was assessed at the beginning of each season by means of Ve.Pro.L.G.s 2008 software [3], a user- 
friendly application to support both design and evaluation of drip systems according to lateral type and length, manifold length and diameter, field slopes and working pressure [4]. Estimated values of DUlq ranged from 0.90 to 0.97 , a sign of the farmers' capacity. DUlq of sprinkler systems was not measured, since irrigation was carried out during night and day and under different wind conditions. Hose reel machines used in the project activity had pipe diameters from $\varnothing 110 \mathrm{~mm}$ to $\varnothing 140 \mathrm{~mm}$ and pipe length from $300 \mathrm{~m}$ to $500 \mathrm{~m}$.

\subsection{Irrigation water requirements}

\subsubsection{Crop evapotranspiration}

Crop evapotranspiration (ETc) was calculated on daily basis by multiplying reference evapotranspiration (ETo) by crop coefficient (kc). Since daily meteorological data requested by Penman-Monteith equation were not available in the project areas, ETo during the irrigation seasons was estimated by using Hargreaves formula [5]:

$$
E T_{o}=C^{*} R a^{*}\left(T_{\text {med }}+17.8\right) * \sqrt{T_{\max }-T_{\min }}
$$

where:

$-\mathrm{ET}_{\mathrm{o}}=$ reference evapotranspiration $\left(\mathrm{mm} \mathrm{d}^{-1}\right)$;

$-\mathrm{T}_{\max }, \mathrm{T}_{\min }$ and $\mathrm{T}_{\text {med }}=$ daily maximum, minimum and mean air temperatures $\left({ }^{\circ} \mathrm{C}\right)$

respectively;

$-\mathrm{C}=0.0023$ is the original empirical constant proposed by Hargreaves and

Samani;

$-\mathrm{Ra}=$ water equivalent of the extraterrestrial radiation $\left(\mathrm{mm} \mathrm{d}^{-1}\right)$.

Hargreaves formula is said to overestimate ETo in sub-humid environment such as that of the research areas. According to studies carried out in similar climatic conditions [6-8], average overestimation is about $10 \%$, the value used here for ETo adjustment.

Evaporation from the soil surface is due to wetted area exposed to sunlight and air ventilation, and depends on the characteristics of irrigation system and canopy coverage [9]. Taking into account the wetted fraction of the soil, the development of crop canopy, and the irrigation frequency, kc during initial and development stage were reduced in the computation of water requirements of drip irrigated crops, as proposed by FAO [10]. Due to specific cropping technique and lateral spacing, this procedure was applied to Tobacco and processing Tomato, resulting in $5 \%$ and $15 \%$ of NIR reduction respectively. Calculation of Onion ETc does not consider irrigation characteristics, since partial wetting is not allowed by the cultivation technique. 


\subsubsection{Effective rainfall}

During a given time period, NIR was calculated as the difference between accumulated daily ETc and effective rainfall (ER). ER was evaluated as follows [11]:

$$
E R=f c\left(1.253 R^{0.824}-2.935\right)\left(10^{0.001 \mathrm{ETc}}\right)
$$

where:

$-\mathrm{fc}=$ correction factor $[/]$ depending on available soil water, $\mathrm{AW}(\mathrm{mm})$, and calculated as:

$\mathrm{fc}=-0.0000000015823427^{*} \mathrm{AW}^{4}+0.0000008546904017^{*} \mathrm{AW}^{3}-$ $0.00017 * \mathrm{AW}^{2}+0.01556 * \mathrm{AW}+0.4783$;

$-\mathrm{R}=$ accumulated rainfall $(\mathrm{mm})$;

$-\mathrm{ETc}=$ crop evapotranspiration during the period $(\mathrm{mm})$.

\subsection{Irrigation supply}

Each irrigation system was equipped with volumetric water meter, in order to measure the amount of water supplied during each irrigation and at the end of the season (SIS).

\subsection{Irrigation efficiency}

Irrigation efficiency (IE) is defined as [12] the ratio between the volume of irrigation water beneficially used, and the total volume of irrigation water applied that leaves the reference physical boundaries within a specific time interval (e.g., an entire irrigation season).

During the research seasons, the only beneficial use conceived by farmers was to compensate for ET losses. Reference boundary was the field edge, and applied irrigation water left the boundary (e.g., the soil surface) within the entire season. Under the cited conditions, IE of each case study can be calculated as NIR/SIS ratio [13].

\section{Results and discussion}

\subsection{Crop response}

Onion, processing Tomato and Tobacco were cultivated during the research period. For each case study, analysis was made on soil type (Soil), gross yield (GY), rejected yield (Rj) and marketable yield (MY).

Expected crop performance, in quantity and quality (e.g., maximum and fine yields), were achieved by all farmers during the project period. Production results refer to harvested crop (e.g., the entire field), not to samples. Crop yield response varies among farms and seasons, according to a fashion that looks independent from irrigation supply. From the economic point of view, no evidence of the advantage of a specific irrigation type was found [14].

Productions of different case studies are reported in table 1. 
Table 1: $\quad$ Crop response in different comparisons (C).

\begin{tabular}{|c|c|c|c|c|c|c|c|c|}
\hline $\begin{array}{l}\mathrm{C} \\
\#\end{array}$ & $\begin{array}{l}\text { Farm } \\
\text { code }\end{array}$ & Crop & System & Soil & $\begin{array}{c}\text { GY } \\
(\mathrm{q} / \mathrm{ha})\end{array}$ & $\begin{array}{l}\mathrm{Rj} \\
(\%)\end{array}$ & $\begin{array}{c}\text { MY } \\
\text { (q/ha) }\end{array}$ & ${ }^{\circ}$ Brix \\
\hline \multirow{2}{*}{1} & \multirow{2}{*}{ BO-2 } & \multirow{2}{*}{ Onion } & Sprinkler ${ }^{(*)}$ & Clay loam & 541 & 7.5 & 500 & \\
\hline & & & Drip & Clay loam & 568 & 10.0 & 511 & \\
\hline \multirow{2}{*}{2} & \multirow{2}{*}{ FE-1 } & \multirow{2}{*}{$\begin{array}{c}\text { Processing } \\
\text { Tomato }\end{array}$} & Sprinkler & Loam & 920 & 3.0 & 892 & 5.6 \\
\hline & & & Drip & Clay loam & 804 & 3.0 & 780 & 4.9 \\
\hline \multirow{2}{*}{3} & \multirow{2}{*}{ PR-1 } & \multirow{2}{*}{$\begin{array}{l}\text { Processing } \\
\text { Tomato }\end{array}$} & Sprinkler & Clay loam & 623 & 4.6 & 594 & 5.7 \\
\hline & & & Drip & Loam & 718 & 4.6 & 685 & 6.2 \\
\hline \multirow{2}{*}{4} & \multirow{2}{*}{ VR-1 } & \multirow{2}{*}{ Tobacco } & Sprinkler & Sandy loam & 205 & 0 & 205 & \\
\hline & & & Drip & Sandy loam & 195 & 0 & 195 & \\
\hline \multirow{2}{*}{5} & \multirow{2}{*}{ BO-2 } & \multirow{2}{*}{ Onion } & Sprinkler $^{(*)}$ & Clay & 484 & 4.5 & 462 & \\
\hline & & & Drip & Clay & 414 & 4.5 & 395 & \\
\hline \multirow{2}{*}{6} & \multirow{2}{*}{ FE-3 } & \multirow{2}{*}{$\begin{array}{c}\text { Processing } \\
\text { Tomato }\end{array}$} & Sprinkler & Loam & 780 & 4 & 750 & 5.3 \\
\hline & & & Drip & Loam & 780 & 4 & 750 & 5.0 \\
\hline \multirow{2}{*}{7} & \multirow{2}{*}{ PR-1 } & \multirow{2}{*}{$\begin{array}{l}\text { Processing } \\
\text { Tomato }\end{array}$} & Sprinkler & Clay loam & 665 & 6.7 & 620 & 6.1 \\
\hline & & & Drip & Clay loam & 755 & 5.8 & 711 & 5.7 \\
\hline \multirow{2}{*}{8} & \multirow{2}{*}{ VR-1 } & \multirow{2}{*}{ Tobacco } & Sprinkler & Clay loam & 225 & 0 & 225 & \\
\hline & & & Drip & Clay loam & 226 & 0 & 226 & \\
\hline \multirow{2}{*}{9} & \multirow{2}{*}{ BO-2 } & \multirow{2}{*}{ Onion } & Sprinkler & Clay loam & 585 & 15 & 497 & \\
\hline & & & Drip & Clay loam & 568 & 10 & 511 & \\
\hline \multirow{2}{*}{10} & \multirow{2}{*}{ PR-1 } & \multirow{2}{*}{$\begin{array}{c}\text { Processing } \\
\text { Tomato }\end{array}$} & Sprinkler & Loam & 901 & 4.4 & 861 & 5.1 \\
\hline & & & Drip & Clay loam & 930 & 3.1 & 901 & 5.5 \\
\hline \multirow{2}{*}{11} & \multirow{2}{*}{ VR-1 } & \multirow{2}{*}{ Tobacco } & Sprinkler & Sandy & 224 & 0 & 224 & \\
\hline & & & Drip & Loam & 228 & 0 & 228 & \\
\hline
\end{tabular}

${ }^{(*)}$ Boom

\subsection{Irrigation efficiency}

Irrigation efficiency was assessed for each case study according to the approach discussed in 2.4. Evaluation procedure is referred to the methodology proposed by Perry [15] recently, and is based on the principle of continuity of mass. Destination of irrigation water is affected by the characteristics of the irrigation system and by management. System efficiency (SE) is characterized by intrinsic losses, depending on the specific features of the system itself. Based on this approach, default values of SE proposed for drip and travelling gun are $95 \%$ and $78 \%$ respectively [13]. Management can increase the specific losses and generate other losses. Different water destinations can be computed by developing the water balance approach, where spray evaporation, wind drift and plant interception are typical destinations of the water supplied by sprinkler systems [13], whereas surface runoff primarily occurs under center pivot and big guns and is minimal under drip irrigation. According to the water balance approach, deep percolation is the water destination generated by both drip and sprinkler irrigation. 
Water flows characterizing the IE of each case study are reported in table 2, together with the number of irrigations (IRR) supplied during the season.

Table 2: Water flows and irrigation efficiencies in different comparisons (C).

\begin{tabular}{|c|c|c|c|c|c|c|c|}
\hline $\begin{array}{l}\mathrm{C} \\
\#\end{array}$ & $\begin{array}{l}\text { Farm } \\
\text { code }\end{array}$ & System & $\begin{array}{c}\text { ER } \\
(\mathrm{mm})\end{array}$ & $\begin{array}{c}\text { NIR } \\
(\mathrm{mm})\end{array}$ & $\begin{array}{c}\text { SIS } \\
(\mathrm{mm})\end{array}$ & $\begin{array}{c}\text { IRR } \\
\text { (n.) }\end{array}$ & $\begin{array}{l}\text { IE } \\
(\%)\end{array}$ \\
\hline \multirow{2}{*}{1} & \multirow{2}{*}{ BO-2 } & Sprinkler & \multirow{2}{*}{64} & 192 & 268 & 6 & 72 \\
\hline & & Drip & & 192 & 303 & 13 & 63 \\
\hline \multirow{2}{*}{2} & \multirow{2}{*}{ FE-1 } & Sprinkler & \multirow{2}{*}{131} & 141 & 160 & 5 & 88 \\
\hline & & Drip & & 93 & 115 & 10 & 81 \\
\hline \multirow{2}{*}{3} & \multirow{2}{*}{ PR-1 } & Sprinkler & 60 & 171 & 194 & 4 & 88 \\
\hline & & Drip & 89 & 140 & 245 & 14 & 57 \\
\hline \multirow{2}{*}{4} & \multirow{2}{*}{ VR-1 } & Sprinkler & \multirow{2}{*}{0} & 162 & 189 & 10 & 86 \\
\hline & & Drip & & 154 & 238 & 11 & 65 \\
\hline \multirow{2}{*}{5} & \multirow{2}{*}{ BO-2 } & Sprinkler & \multirow{2}{*}{348} & 150 & 224 & 7 & 67 \\
\hline & & Drip & & 150 & 241 & 14 & 62 \\
\hline \multirow{2}{*}{6} & \multirow{2}{*}{ FE-3 } & Sprinkler & \multirow{2}{*}{211} & 100 & 133 & 5 & 75 \\
\hline & & Drip & & 85 & 171 & 38 & 50 \\
\hline \multirow{2}{*}{7} & \multirow{2}{*}{ PR-1 } & Sprinkler & \multirow{2}{*}{334} & 94 & 120 & 3 & 78 \\
\hline & & Drip & & 80 & 204 & 13 & 39 \\
\hline \multirow{2}{*}{8} & \multirow{2}{*}{ VR-1 } & Sprinkler & \multirow{2}{*}{237} & 106 & 125 & 7 & 85 \\
\hline & & Drip & & 101 & 129 & 9 & 78 \\
\hline \multirow{2}{*}{9} & \multirow{2}{*}{ BO-2 } & Sprinkler & \multirow{2}{*}{103} & 182 & 223 & 8 & 82 \\
\hline & & Drip & & 150 & 238 & 14 & 63 \\
\hline \multirow{2}{*}{10} & \multirow{2}{*}{ PR-1 } & Sprinkler & 68 & 230 & 263 & 8 & 87 \\
\hline & & Drip & 71 & 196 & 348 & 24 & 56 \\
\hline \multirow{2}{*}{11} & \multirow{2}{*}{ VR-1 } & Sprinkler & \multirow{2}{*}{94} & 123 & 188 & 11 & 65 \\
\hline & & Drip & & 117 & 144 & 12 & 81 \\
\hline
\end{tabular}

Average IE of sprinkler and drip is $79.4 \%$ and $63.2 \%$ respectively. Moreover, sprinkler performs better than drip in all cases with the exception of $\mathrm{C} \# 11$, and average IE is very close to the default value of SE. Within the limits of the research, such as the sample size, it seems that hose reel SE is affected neither by field operations (e.g., rewind speed, working pressure/nozzle diameter combination) nor by scheduling activities (e.g., irrigation depth, irrigation time). In other words, system management seems quite simple. On the other hand, dramatic drop of drip IE from default SE (-35\%) indicates some difficulty in system operation. Under these assumptions, the gap of actual IE from default SE seems to depend on management. This assertion is supported by the coefficient of variation $(\mathrm{CV})$ of sprinkler and drip IE referred to the 11 comparisons. $\mathrm{CV}$ and interval (e.g., max-min) of IE are $10.10 \%$ and 23 under sprinkler, $24.63 \%$ and 42 under drip.

Taking into account of the research limitations, CV and interval of drip IE should be noted. In particular, CV values below $15 \%$ indicate a homogeneous set 
of data [16]. In this case, IE under hose reel sprinkler systems seems to be subjected to smaller variations with respect to drip.

\section{Conclusions}

In the framework and limitations of the research conditions, results of the triennial project show that similar production performance can be achieved under different irrigation efficiencies. In most cases, hose reel sprinkler systems meet the reference values of SE proposed by latest technical bibliography. On the other hand, and in spite of farmers' experience and skills, seasonal irrigation efficiency under drip systems is by far below its potential. Variation of IE is lower under sprinkler than drip irrigation, suggesting that drip performance can be heavily affected by management during the season. Irrigation efficiency in the case study was assessed according to the water balance at soil surface. This way does not clarify the destination of water infiltrated into the soil, that can leave the designated region (e.g., percolate below the active root profile) or be stored in the soil (e.g., no variation or increase from the beginning of the period). According to project outcomes, water balance should be approached at field level in a 3-dimension space to assess whether deep percolation is the common destination of water under inefficient drip and sprinkler irrigation.

\section{References}

[1] Ghinassi, G. and Cecchi S., Rapid assessment of seasonal in-field water management on micro irrigated annual and perennial crops in Central Italy. Proc. of the $7^{\text {th }}$ Asian Regional Conference, $63^{\text {rd }}$ IEC of the ICID, Adelaide, Australia, 2012.

[2] SEAgrIT project http://risorseidriche.arsia.toscana.it/pagebase.asp? $\mathrm{p}=1029$

[3] Ve.Pro.L.G.s 2008, Verifica e Progettazione di Linee Gocciolanti e Settori d'impianto per il risparmio di acqua e di energia http://risorseidriche.arsia.toscana.it/pagebase.asp? $\mathrm{p}=253$

[4] Ghinassi, G. and Bertolacci, M., Increasing actual drip irrigation performance by system design and maintenance. The potential of Ve.Pro.L.G.s 2008 support tool. Proc. of the 3r Congreso sobre Agricultura, Alimentaciòn y Medio Ambiente: la gestion del $\mathrm{H}_{2} \mathrm{O}$, usos y eficiencias, UPC, Castelldefels, Spain, ISBN 978-8461-3051-00, pp. 11-17, 2009.

[5] Hargreaves, G.H. and Samani, Z.A., Reference crop evapotranspiration from temperature. Applied Engineering in Agriculture 1(2), pp. 96-99, 1985.

[6] Dal Monte, G., Perini, L.and Thiery F., Studio dell'evapotraspirazione di riferimento nei comprensori irrigui delle regioni obiettivo 1. Uso integrato delle formule di Hargreaves-Samani e Penman-Monteith. Convegno nazionale L'Agrometeorologia per il Monitoraggio dei Consumi Idrici, Sassari, 1999. 
[7] Di Lena, B. and Acutis M., Confronto tra stime dell'evapotraspirazione di riferimento ai fini dell'assistenza tecnica irrigua in Abruzzo, atti del Convegno AIAM 2002, Acireale.

[8] Viglione, A., Stima dell'Evapotraspirazione media mensile sul territorio Piemontese, Working Paper 2004 - Dipartimento di Idraulica, Trasporti e Infrastrutture Civili, Politecnico di Torino, 2004.

[9] Reinders, F.B., Improved efficiency of irrigation water use: A South African framework. Proc. of the 21st Congress of the ICID, ISBN 9788189610111, Teheran, pp. 179-194, 2011.

[10] Allen, R.G., Pereira, L.S., Raes, D. and Smith, M., Crop evapotranspiration: Guidelines for computing crop water requirements, FAO Irrigation and Drainage Paper no. 56, Rome, pp. 147-151.

[11] USDA, Irrigation water requirements. Technical Release n. 21, USDA Soil Conservation Service, 1970.

[12] Burt, C.M., Clemmens, A.J., Strelkoff T.S., Solomon K.H., Bliesner R.D., Hardy L.A., Howell T.A. and Eisenhauer D.E., Irrigation performance measures: Efficiency and Uniformity, Biological Systems Engineering: Papers and Publications, University of Nebraska, Lincoln, 1997.

[13] ARC-Agricultural Research Council, Standards and Guidelines for improved efficiency of irrigation water use from dam wall release to root zone application, Water Research Commission Report no. TT466/10, ISBN 978-1-4312-0023-8, pp. 34-37, 2010.

[14] Ghinassi, G., Zammarchi, L. and Cecchi, S., Economic response of industrial crops to drip and hose-reel irrigation: on-farm comparisons in central and northern Italy. Proc. of the $21^{\text {st }}$ Congress of the ICID, Teheran, ISBN 9788189610111, pp. 163-178, 2011.

[15] Perry, C., Efficient irrigation; inefficient communication; flawed recommendations. Irrigation and Drainage, 56, pp. 367-378, Wiley InterScience, 2007.

[16] Castino, M.and Roletto, E., Statistica applicata, Piccin Editore, Padova, ISBN 88-299-0935-1, pp. 79-88, 1991. 